\title{
Carbon, nitrogen, and phosphorus stoichiometry of organic matter in Swedish forest soils and its relationship with climate, tree species, and soil texture
}

5 Marie Spohn ${ }^{1}$, Johan Stendahl ${ }^{1}$

${ }^{1}$ Department of Soil and Environment, Swedish University of Agricultural Sciences (SLU), Lennart Hjelms väg 9, P.O. Box 7014, 75007 Uppsala, Sweden

Correspondence to: Marie Spohn (marie.spohn@slu.se)

Abstract. While the carbon (C) content of temperate and boreal forest soils is relatively well studied, much less is known them. Therefore, the aim of this study was to explore carbon, nitrogen, and organic phosphorus (OP) contents and element ratios in temperate and boreal forest soils and their relationships with climate, dominant tree species, and soil texture. For this purpose, we studied 309 forest soils with a stand age $>60$ years located all over Sweden between $56^{\circ} \mathrm{N}$ and $68^{\circ} \mathrm{N}$. The soils are a representative subsample of Swedish forest soils with a stand age $>60$ years that were sampled for the Swedish Forest Soil Inventory. We found that the $\mathrm{N}$ stock of the organic layer increased by a factor of 7.5 from $-2^{\circ} \mathrm{C}$ to $7.5^{\circ} \mathrm{C}$ mean annual temperature (MAT), it increased almost twice as much as the organic layer stock along the MAT gradient. The increase in the $\mathrm{N}$ stock went along with an increase in the $\mathrm{N}: \mathrm{P}$ ratio of the organic layer by a factor of 2.1 from $-2^{\circ} \mathrm{C}$ to $7.5^{\circ} \mathrm{C}$ MAT $\left(\mathrm{R}^{2}=0.36\right.$,

$20 \mathrm{p}<0.001)$. Forests dominated by pine had higher $\mathrm{C}: \mathrm{N}$ ratios in the litter layer and mineral soil down to a depth of $65 \mathrm{~cm}$ than forests dominated by other tree species. Further, also the C:P ratio was increased in the pine-dominated forests compared to forests dominated by other tree species in the organic layer, but the C:OP ratio in the mineral soil was not elevated in pine forests. C, N and OP contents in the mineral soil were higher in fine-textured soils than in coarse-textured soils by a factor of $2.3,3.5$, and 4.6, respectively. Thus, the effect of texture was stronger on OP than on $\mathrm{N}$ and C, likely because OP adsorbs very

25 rigidly to mineral surfaces. Further, we found, that the $\mathrm{P}$ and $\mathrm{K}$ concentrations of the organic layer were inversely related with the organic layer stock. The $\mathrm{C}$ and $\mathrm{N}$ concentrations of the mineral soil were best predicted by the combination of MAT, texture, and tree species, whereas the OP concentration was best predicted by the combination of MAT, texture and the P concentration of the parent material in the mineral soil. In the organic layer, the P concentration was best predicted by the organic layer stock. Taken together, the results show that the N:P ratio of the organic layer was most strongly related to MAT.

30 Further, the $\mathrm{C}: \mathrm{N}$ ratio was most strongly related to dominant tree species, even in the mineral subsoil. In contrast, the C:P ratio was only affected by dominant tree species in the organic layer, but the C:OP ratio in the mineral soil was hardly affected by tree species due to the strong effect of soil texture on the OP concentration. 
https://doi.org/10.5194/bg-2021-346

Preprint. Discussion started: 22 December 2021

(c) Author(s) 2021. CC BY 4.0 License.

\section{(c) (i)}

\section{Introduction}

35 Temperate and boreal forests store large amounts of soil organic matter (SOM) (Bradshaw and Warkentin, 2015; Tau-Strand et al., 2016; Hounkpatin et al., 2021). While most studies on SOM in temperate and boreal forests concentrated exclusively on carbon (C), and some studies also included nitrogen (N) and investigated the C:N ratio (Callesen et al., 2007; Cools et al., 2014; Tau-Strand et al., 2016), very few studies explored the phosphorus (P) content, and the C:P and N:P ratios of SOM in forests (for an exception see Tipping et al., 2016), particularly in North European forests. Thus, we lack knowled ge about the

$40 \mathrm{C}: \mathrm{N}: \mathrm{P}$ stoichiometry of the organic matter of temperate and boreal forest soils and the factors that control it.

The $\mathrm{N}$ stock of well-drained temperate and boreal forest soils in Northern Europe increases with increasing mean annual temperature (MAT) (Callesen et al., 2007). Yet, it is unknown whether organic $\mathrm{P}$ (OP) increases in the same way as $\mathrm{N}$ along the MAT gradient in Northern Europe or if the N:P ratio of SOM changes with MAT in North European forest soils. If P availability is high enough to balance the elevated $\mathrm{N}$ availability at sites with high $\mathrm{N}$ availability and high MAT, the N:P ratio of SOM in North European forests will likely not change with MAT. However, several studies question whether P availability is sufficient to balance the high rates at which $\mathrm{N}$ is incorporated into plant biomass in N-rich European forests (Flückiger and Braun, 1998; Braun et al., 2010; Talkner et al., 2015; Jonard et al., 2015; Heuck et al., 2018), which will lead to an increased $\mathrm{N}: \mathrm{P}$ ratio. In particular, it has been suggested based on modeling exercises that high $\mathrm{N}$ availability in South Sweden might lead to P limitations in trees and elevated foliage N:P ratios in South Swedish forests (Akselsson et al., 2008; Yu et al., 2018),

50 which likely translates into high N:P ratios of plant litter and potentially of SOM (Zechmeister-Boltenstern et al., 2015). Yet, on the other hand, it has to be considered that most soils in Northern Europe are only between 9,000 and 14,000 years old. Thus, comparatively little $\mathrm{P}$ leaching and $\mathrm{P}$ occlusion has likely occurred during the short duration of pedogenesis, resulting probably in a relatively high $\mathrm{P}$ availability in soils of all climate regimes, which should be able to balance the high $\mathrm{N}$ availability at sites with high MAT. Taken together, it is currently still an open question if and how the N:P ratio of SOM in Swedish

55 forests soils changes with organic matter N stock and MAT.

Several studies showed that the C:N ratios of the organic layer and the mineral topsoil of forests in North Europe are affect by the dominant tree species (Vesterdal and Raulund-Rasmussen, 1998; Vesterdal et al., 2008; Hansson et al. 2011; Cools et al. 2014). In particular, it has been reported that the organic layers of pine forests have a higher $\mathrm{C}: \mathrm{N}$ ratio than spruce and deciduous forests (Vesterdal and Raulund-Rasmussen, 1998; Vesterdal et al., 2008; Hansson et al. 2011; Cools et al. 2014). However, little is known about the $\mathrm{C}: \mathrm{N}$ ratio in the mineral soil below the uppermost $10 \mathrm{~cm}$. Furthermore, very little is known about the relationship between dominant tree species and the $\mathrm{C}: \mathrm{OP}$ and N:OP ratio of the organic layer and the mineral soil in forests in North Europe (for exceptions see Vesterdal and Raulund-Rasmussen, 1998; Hansson et al., 2011).

Besides climate and tree species, the SOM stoichiometry is likely also affected by soil texture. Recent research showed that OP is more strongly enriched in the clay-size fraction than organic $\mathrm{C}$ because OP compounds adsorb rigidly to mineral surfaces 65 in soils (Spohn, 2020a). This suggests that OP has also higher concentrations in fine-textured than in coarse-textured soils 
https://doi.org/10.5194/bg-2021-346

Preprint. Discussion started: 22 December 2021

(c) Author(s) 2021. CC BY 4.0 License.

\section{(c) (1)}

because the adsorption of organic compounds protects them against microbial decomposition, and thus should lead to a preferential enrichment of the compounds that adsorb particularly strong, in soils that provide many sorption sites. Further, it seems likely that besides $\mathrm{OP}, \mathrm{N}$ is also enriched in fine-textured soils because a large part of $\mathrm{N}$ is present in SOM in the form of charged nitrate or ammonium groups that can adsorb to charged surfaces (Knicker et al., 1993; Jones and Hodges, 1999;

70 Kopittke et al., 2018; Miltner et al., 2009). However, previous studies on the effect of texture on the soil $\mathrm{N}$ concentration and the C:N ratios in North European forest soils arrived at contradicting conclusions (Vejre et al., 2003; Callesen et al., 2007).

The aim of this study was to explore the $\mathrm{C}, \mathrm{N}$, and OP contents and element ratios in temperate and boreal forest soils in Sweden and their relationships with climate, dominant tree species, and soil texture. We hypothesized, first, that while the $\mathrm{N}$ stock of the organic layer increases with increasing MAT, the N:P ratio of the organic layer does not change with MAT. We hypothesized second, that the C:OP ratio of the organic layer and mineral soil shows similar differences between forests with different tree species as the $\mathrm{C}: \mathrm{N}$ ratio. Third, we hypothesized that organic matter is $\mathrm{N}$ - and P-richer in fine-textured than in coarse-textured mineral soils. In order to test these hypotheses, we studied 309 forest soils with a forest stand age >60 years located all over Sweden between $56^{\circ} \mathrm{N}$ and $68^{\circ} \mathrm{N}$. The soils are a representative subsample of Swedish forest soils with a stand age $>60$ years that were sampled for the Swedish Forest Soil Inventory. We selected sites with a stand age $>60$ years in order to minimize the effect of forest management on the results.

\section{Material and Methods}

\subsection{Data collection, sampling, and sample preparation}

Data and soil samples were collected for the Swedish Forest Soil Inventory (SFSI), which is conducted together with the

85 National Forest Inventory (Riksskogstaxeringen) since 1923. The SFSI in its current form started in 1983 and monitors the state of the Swedish forests with respect to soil and vegetation. It covers all of Sweden except for arable land and urban areas. The inventory visits about 20,000 permanent plots over a 10-year period, sampling every year about 2,000 plots distributed all over Sweden. Circular plots with $10 \mathrm{~m}$ radius are located in quadratic clusters on a triangular grid (Ranneby et al., 1987), which is denser towards the south of the country to account for the greater fragmentation of the landscape and a more diverse

90 geology in the south of Sweden. Each quadratic cluster encompasses 8 circular plots (4 in the southwestern region; Ranneby et al., 1987). At each of these circular plots the dominant tree species is classified according to the following classes based on basal area; Deciduous, Mixed (mainly mixed coniferous forests), Pine (Pinus sylvestris + Pinus contorta), and Spruce (Picea abies). The diameter at breast height is determined for all trees, and from the differences over 10 years, the stem growth rate of the trees at plot level is calculated. A loss of one or more tree(s) can therefore result in a decline in standing volume between

95 inventories, and thus a negative stem growth rate. In addition, the stand age is determined from the stand history assessed by the repetitive inventory together with tree drillings in the 1980 s. 
https://doi.org/10.5194/bg-2021-346

Preprint. Discussion started: 22 December 2021

(c) Author(s) 2021. CC BY 4.0 License.

\section{(c) (i)}

Soil sampling is carried out on a subset of the circular plots, i.e. organic layer sampling on c. 10,000 plots and mineral soil sampling on c. 4,500 plots. The organic layer is sampled volumetrically using a $10 \mathrm{~cm}$ diameter corer in a $3.14 \mathrm{~m}^{2}$ subplot within each circular plot throughout the entire depth of the organic layer (up to $30 \mathrm{~cm} \mathrm{depth),} \mathrm{excluding} \mathrm{the} \mathrm{litter} \mathrm{layer.} \mathrm{To}$ gain a sample of about 1.5 liter, 1-9 volumetric samples are combined. In addition, a small soil profile is prepared in the subplot. The soil order is determined according to WRB (FAO, 2013), and mineral soil is collected at fixed depth intervals: 0 $10 \mathrm{~cm}, 10-20 \mathrm{~cm}$, and $55-65 \mathrm{~cm}$. The texture of the mineral soil samples is determined in the field according to the following classes; clay (8), fine silt (7), coarse silt (6), fine sand (5), sand (4), and coarse sand (3). In the laboratory, all soil samples are dried to constant weight at $35^{\circ} \mathrm{C}$. The samples are homogenized and sieved $(<2 \mathrm{~mm})$, and living and dead roots $>1 \mathrm{~mm}$ diameter are removed. The samples are weighed and the stock of the organic layer is calculated based on the weight of the fraction $<2$ $\mathrm{mm}$ of the organic layer. Chemical analyses are carried out on the fine soil fraction $(<2 \mathrm{~mm})$.

For the present study, we selected plots that (i) have been sampled between 2013 and 2018, (ii) were vegetated by forest with a long-term productivity $>1 \mathrm{~m}^{3} \mathrm{yr}^{-1}$ and a stand age $>60$ years, (iii) had the humus form mor or moder (which excludes peatland), and (iv) for which data on the concentration of $\mathrm{P}$ in the parent material was available (Olsson et al., 1993). The plot selection based on these four criteria resulted in a total number of 309 plots (Fig. 1). Of these, 203 were podzols, 84 were regosols, 12 were arenosols, and each three soils were classified as either leptosol, gleysol or cambisol, while one soil was an umbrisol. The mean stand age was 113 years. In the following the plots are also referred to as forests.

\subsection{Soil chemical analyses and climate data}

Most soil chemical analyses were conducted for the Swedish Forest Soil Inventory based on the samples taken between 2013 and 2018. The total $\mathrm{C}$ and $\mathrm{N}$ content was analyzed using an elemental analyzer (TruMac CN, LECO). pH was determined in water (soil: water ratio 1:2.5) using a Pt electrode (Aquatrode plus Pt1000, Methrom). Exchangeable cations (Ca, Mg, Na, K, and $\mathrm{Mn}$ ) were extracted in $1 \mathrm{M}$ ammonium acetate buffered at $\mathrm{pH} 7.00$ and analyzed by inductively coupled plasma optical emission spectroscopy (ICP-OES; Avivo 200, Perkin Elmer).

In addition to the variables determined for the Swedish Forest Soil Inventory, we determined total P and organic P for the present study based on the samples taken between 2013 and 2018. Total P of the organic layer and the mineral soil in a depth of 0-10 $\mathrm{cm}$ was extracted in nitric acid and hydrogen peroxide (in a ratio 1:3) in a microwave system (Ethos Easy, Milestone) according to the instructions of the manufacturer, and P was determined using ICP-OES (Avivo 200, Perkin Elmer) after filtration of the extract.

Organic $\mathrm{P}$ in the mineral soil in a depth of 0-10 $\mathrm{cm}$ was determined according to Saunders and Williams (1955) and William and Saunders (1956) as specified in Pansu and Gautheyrou (2006). Briefly, each sample was separated in two aliquots, each of $1 \mathrm{~g}$. The first aliquot was directly extracted in $0.5 \mathrm{M} \mathrm{H}_{2} \mathrm{SO}_{4}$ on a horizontal shaker for $16 \mathrm{~h}$. The other aliquot was ignited at $550^{\circ} \mathrm{C}$ for $2 \mathrm{~h}$ and subsequently extracted in $\mathrm{H}_{2} \mathrm{SO}_{4}$ in the same way as the non-ignited sample. Inorganic $\mathrm{P}$ was measured 
https://doi.org/10.5194/bg-2021-346

Preprint. Discussion started: 22 December 2021

(c) Author(s) 2021. CC BY 4.0 License.

(c) (i)

in the extracts by the molybdenum blue method according to Murphy and Riley (1962) using a continuous flow system (AA500, Seal). Total organic $\mathrm{P}$ was calculated as the difference between inorganic $\mathrm{P}$ in ignited and non-ignited samples.

Total $\mathrm{C}$ in this study is considered organic $\mathrm{C}$ since all soils were acidic. Furthermore, total $\mathrm{P}$ in the organic layer is considered to be organic P. For the mineral soil, we specify whether we refer to organic or total $\mathrm{P}$, in the following.

135 Total $\mathrm{P}$ in the parent material was determined on samples that were collected from the $\mathrm{B} / \mathrm{C}$ and $\mathrm{C}$ horizon for the SFSI in the 1980s. The samples were ground, sieved $(<2 \mathrm{~mm})$, ignited and fused with lithium-metaborate, and subsequently, total P was determined by ICP (Olsson et al., 1993).

Other data used in this study are mean annual temperature (MAT; from 2012), mean annual precipitation (MAP; from 2012) and total N deposition (NDep; from 1998) retrieved from the Swedish Meteorological and Hydrological Institute

140 (https://www.smhi.se/data). We assume that the $\mathrm{N}$ deposition flux data of the year 1998 is representative for historic $\mathrm{N}$ deposition fluxes in Sweden during the last decades which were highest in the 1990s.

\subsection{Data analysis}

For the analysis of soil texture, the texture class clay (8) and fine silt (7) were combined as well as the texture class sand (4),

145 and coarse sand (3). Organic layer element stocks were calculated by multiplying the organic layer stock with the respective element concentration. We calculated linear models, power function, medians and arithmetic means, and conducted regression analysis in $\mathrm{R}$ (version 4.1.1, R Core Team, 2003). For the multiple regression analysis, the variable $\mathrm{N}$ tree was created with the value 1 for pine, 2 for mixed and spruce forests and 3 for deciduous forests. All correlations referred to in the text are significant at $\mathrm{p}<0.001$, and individual $\mathrm{p}$ values for specific correlations are given in the tables and figures.

\section{Results}

\subsection{Mean annual temperature, $\mathrm{N}$ deposition, and SOM stoichiometry}

We found correlations between the organic layer stock, $\mathrm{C}, \mathrm{N}$ and $\mathrm{P}$ contents as well as element ratios with latitude, MAT, and

$155 \mathrm{~N}$ deposition, but hardly with MAP (Table 1). Due to the skewness of the $\mathrm{N}$ deposition rates, the correlation analysis was conducted with log-transformed $\mathrm{N}$ deposition rates (Table 1).

The $\mathrm{N}$ stock of the organic layer was positively correlated with MAT $\left(\mathrm{R}^{2}=0.23\right.$, Fig. 2a) and with the log-transformed $\mathrm{N}$ deposition $\left(\mathrm{R}^{2}=0.26\right)$, and negatively with latitude $\left(\mathrm{R}^{2}=0.22\right.$; Table 1$)$. In the linear model fitted to the empirical data, the $\mathrm{N}$ stock of the organic layer increased by a factor of 7.5 from $192 \mathrm{~kg} \mathrm{ha}^{-1}$ at $-2^{\circ} \mathrm{C}$ MAT to $1439 \mathrm{~kg} \mathrm{ha}^{-1}$ at $7.5^{\circ} \mathrm{C}$ MAT (Fig. 2a).

160 The organic layer stock was positively correlated with MAT $\left(\mathrm{R}^{2}=0.13\right.$, Fig. $\left.2 \mathrm{~b}\right)$ and with the log-transformed $\mathrm{N}$ deposition $\left(\mathrm{R}^{2}=0.15\right)$, and negatively with latitude $\left(\mathrm{R}^{2}=0.13\right.$; Table 1$)$. In the linear model fitted to the empirical data, the organic layer stock increased by a factor of 3.9 from $30.7 \mathrm{~kg} \mathrm{ha}^{-1}$ at $-2^{\circ} \mathrm{C}$ MAT to $120.8 \mathrm{~kg} \mathrm{ha}^{-1}$ at $7.5^{\circ} \mathrm{C}$ MAT (Fig. 2b). 
https://doi.org/10.5194/bg-2021-346

Preprint. Discussion started: 22 December 2021

(c) Author(s) 2021. CC BY 4.0 License.

\section{(c) (i)}

Nitrogen deposition was below $1.5 \mathrm{~kg} \mathrm{ha}^{-1}$ year-1 in most forests, but in some it was higher, and in 8 forests it was even between 5.5 and $8 \mathrm{~kg} \mathrm{ha}^{-1}$ year $^{-1}$ (Fig. 2c). The forests with the highest $\mathrm{N}$ deposition rate had mostly intermediately high organic layer

$165 \mathrm{~N}$ stocks (Fig. 2c), thus the $\mathrm{N}$ deposition rate and the $\mathrm{N}$ stock of the organic layer were only loosely related.

Tree stem growth was positively correlated with MAT $\left(\mathrm{R}^{2}=0.27\right.$; Fig. $\left.2 \mathrm{~d}\right)$, and it increased by a factor of 2.5 from $1.87 \mathrm{~m}^{3}$ ha ${ }^{1} \mathrm{yr}^{-1}$ at $-2^{\circ} \mathrm{C}$ MAT to $4.72 \mathrm{~m}^{3} \mathrm{ha}^{-1} \mathrm{yr}^{-1}$ at $7.5^{\circ} \mathrm{C}$ (Fig. 2d).

The C:N ratio of the organic layer was negatively correlated with MAT $\left(\mathrm{R}^{2}=0.08\right.$, Supplement Fig. S1) and with the logtransformed $\mathrm{N}$ deposition $\left(\mathrm{R}^{2}=0.11\right)$ and latitude $\left(\mathrm{R}^{2}=0.08\right.$; Table1). In the linear model fitted to the empirical data, the molar

$\mathrm{C}: \mathrm{N}$ ratio of the organic layer decreased from 55.3 at $-2^{\circ} \mathrm{C}$ MAT to 37.8 at $7.5^{\circ} \mathrm{C}$ MAT (Fig. 2d).

The $\mathrm{P}$ stock of the organic layer was positively correlated with MAT $\left(\mathrm{R}^{2}=0.10\right.$, Fig. 2e) and with the log-transformed $\mathrm{N}$ deposition $\left(R^{2}=0.10\right)$, and negatively with latitude $\left(R^{2}=0.08\right.$; Table 1$)$. In the linear model fitted to the empirical data, the $\mathrm{N}$ stock of the organic layer increased by a factor of 2.3 from $28 \mathrm{~kg} \mathrm{ha}^{-1}$ at $-2^{\circ} \mathrm{C}$ MAT to $65 \mathrm{~kg} \mathrm{ha}^{-1}$ at $7.5^{\circ} \mathrm{C}$ MAT (Fig. 2e).

The N:P ratio of the organic layer was positively correlated with MAT $\left(R^{2}=0.36\right.$, Fig. $\left.2 f\right)$, and negatively with latitude

$\left(\mathrm{R}^{2}=0.36\right)$ and the $\log$-transformed $\mathrm{N}$ deposition $\left(\mathrm{R}^{2}=0.40\right)$. In the linear model fitted to the empirical data, the $\mathrm{N}: \mathrm{P}$ ratio of the organic layer increased by a factor of 2.1 from 24.0 at $-2^{\circ} \mathrm{C}$ MAT to 49.3 at $7.5^{\circ} \mathrm{C}$ MAT (Fig. 2f).

The C:P ratio of the organic layer was only weakly $\left(\mathrm{R}^{2}=0.03\right)$ correlated with latitude, MAT and the log-transformed $\mathrm{N}$ deposition (Table 1). Furthermore, C, N and OP in the mineral soil were only weakly correlated with latitude, MAT, and N deposition (Table 1).

\subsection{Dominant tree species and SOM stoichiometry}

The C:N ratio of the organic layer differed between forests with different dominant tree species (Fig. 3a). The C:N of the organic layer was highest in pine forests, on average 1.8 times higher than in deciduous forests, and 1.3 times higher than in spruce forests (Fig. 3a). A similar relationship between forests dominated by different tree species was observed for the C:N ratio in the mineral soil (Fig. 3b-d). In a depth of $55-65 \mathrm{~cm}$, the $\mathrm{C}: \mathrm{N}$ ratio of the mineral soil in spruce forests was on average 1.8 times higher than in deciduous forests and 1.2 times higher than in spruce forests (Fig. 3d), similar to the organic layer. Some pine forests had very high C:N and C:P ratios due to low $\mathrm{N}$ and $\mathrm{P}$ contents.

The C:P ratio of the organic layer (Fig. 3e) followed a similar pattern as the C:N ratio across forests with different dominant tree species. The C:P ratio of the organic layer in spruce forests was on average 1.3 times higher than in both deciduous and spruce forests (Fig. 3e). In contrast, the C:OP ratio in the mineral soil was not elevated in pine forests but rather in deciduous forests (Fig 2f). The N:P ratio was slightly elevated in deciduous forests, but did not substantially differ between mixed, pine and spruce forest (Supplement Fig. S2a). The organic layer stock differed also between forests with different dominant tree species (Supplement Fig. S2b). In deciduous forests, it was on average 2.2 times higher than in pine forests and 1.9 times higher than in spruce forests. 
https://doi.org/10.5194/bg-2021-346

Preprint. Discussion started: 22 December 2021

(c) Author(s) 2021. CC BY 4.0 License.

(c) (i)

\subsection{Texture and SOM stoichiometry}

Concentrations of $\mathrm{C}, \mathrm{N}$ and $\mathrm{OP}$ in the uppermost $10 \mathrm{~cm}$ of the mineral soil were highest in soils with the texture clay or fine silt (Fig. 4a-c). The concentrations of C, N and OP decreased gradually with increasing particle size from clay and fine silt, to coarse silt, to fine sand, and finally to sand (Fig. 4a-c). C, N and OP contents were higher in soils with the texture clay or fine silt than in soils with the texture sand or coarse sand by a factor of 2.3,3.5, and 4.6, respectively (Fig 3a-c). Thus, the differences in element concentrations between soils with different texture were largest for $\mathrm{OP}$, and decreased in the order $\mathrm{OP}>\mathrm{N}>\mathrm{C}$.

The C:N ratio and the C:OP ratio increased gradually with increasing particle size fraction (Fig. $4 \mathrm{~d}$ and e). The mean C:N ratio and $\mathrm{C}: \mathrm{OP}$ ratio were 1.5 and 1.4 times higher in soils with the texture clay or fine silt than in soils with the texture sand or coarse sand (Fig. 4d and e).

205 Different soil textures were also associated with differences in the $\mathrm{N}$ stock of the organic layer (Fig. 4f). The mean $\mathrm{N}$ stock of the organic layer increased with decreasing particle size, and it was 1.3 times higher in soils with the texture clay or fine silt than in soils with the texture sand or coarse sand (Fig. 4f).

\subsection{Organic layer stock and parent material}

210 The organic layer stock was inversely related with the concentration of exchangeable K in a non-linear way (Fig. 5a), and the variables were correlated when log-transformed $\left(\mathrm{R}^{2}=0.38\right.$; Fig. $\left.5 \mathrm{~b}\right)$. The concentration of exchangeable $\mathrm{K}$ was positively correlated with the $\mathrm{P}$ concentration of the organic layer $\left(\mathrm{R}^{2}=0.66\right.$, Supplement Fig. S3). The organic layer stock was also inversely related with its $\mathrm{P}$ concentration in a non-linear way (Fig. 5c), and the variables were correlated when log-transformed $\left(\mathrm{R}^{2}=0.27\right.$; Fig. 5d). In addition, the concentrations of $\mathrm{N}$ and $\mathrm{Mg}$ in the organic layer were strongly positively correlated $215\left(\mathrm{R}^{2}=0.64\right.$, Supplement Fig. S3).

In the organic layer, $\mathrm{C}$ and $\mathrm{N}\left(\mathrm{R}^{2}=0.82\right)$ as well as $\mathrm{C}$ and $\mathrm{P}\left(\mathrm{R}^{2}=0.71\right)$ and $\mathrm{N}$ and $\mathrm{P}\left(\mathrm{R}^{2}=0.78\right)$ were strongly correlated (Supplement Fig. S4 a, c, e). In the uppermost $10 \mathrm{~cm}$ of the mineral soil, $\mathrm{C}$ and $\mathrm{N}$ were also strongly correlated $\left(\mathrm{R}^{2}=0.82\right.$, Supplement Fig. S4). The data had to be log-transformed to allow correlation analysis for $\mathrm{C}$ and $\mathrm{P}\left(\mathrm{R}^{2}=0.47\right)$ and $\mathrm{N}$ and $\mathrm{P}$ $\left(R^{2}=0.49\right)$ in the uppermost $10 \mathrm{~cm}$ of the mineral soil since the data was not normally distributed (Supplement Fig. S4d and f).

220 In most soils, the $\mathrm{P}$ concentration of the parent material was below $1.0 \mathrm{~g} \mathrm{~kg}^{-1}$, but in a small number of forests it was substantially higher, up to $3.4 \mathrm{~g} \mathrm{~kg}^{-1}$. The log-transformed $\mathrm{P}$ concentration of the parent material was correlated with the total $P$ concentration of the uppermost $10 \mathrm{~cm}$ of the mineral soil $\left(R^{2}=0.26\right.$; correlation not shown), and it was more weakly correlated with the OP concentration of the uppermost $10 \mathrm{~cm}$ of the mineral soil $\left(\mathrm{R}^{2}=0.08\right)$ as well as with the total $\mathrm{P}$ concentration of the organic layer $\left(\mathrm{R}^{2}=0.08\right)$.

\subsection{Covariance}

We also analyzed the relationship between latitude, tree species, and soil texture to understand their covariance. Deciduous forests had a lower latitude than all other forests, while mixed, pine and spruce forests did not differ substantially in latitude 
https://doi.org/10.5194/bg-2021-346

Preprint. Discussion started: 22 December 2021

(c) Author(s) 2021. CC BY 4.0 License.

\section{(c) (i)}

(Fig. S5a). Further, the latitude of forests with different soil texture did not vary substantially (Fig. S5b). Spruce forests tended to have a higher texture class, i.e., a finer soil texture than all other forests, while there was no substantial difference in texture between deciduous, mixed, and pine forest (Fig. S5c).

\subsection{Multiple regressions}

We tested if we could improve the regressions between MAT and several soil properties (Table 1) by including data on texture, dominant tree species, and the $\mathrm{P}$ concentration of the parent material (Table 2). The $\mathrm{C}$ concentration of the mineral soil (0-10 $\mathrm{cm})$ could be substantially better predicted by the combination of MAT and soil texture $\left(\mathrm{R}^{2}=0.20\right.$, Table 2$)$ than by only MAT (Table 1). The $\mathrm{N}$ concentration and the $\mathrm{C}: \mathrm{N}$ ratio of the mineral soil $(0-10 \mathrm{~cm})$ could be substantially better predicted by the combination of MAT, texture, and tree species $\left(\mathrm{R}^{2}=0.22\right.$ and 0.13 , respectively) than by only MAT and texture (Table 2$)$ or only MAT (Table 1). Finally, the OP concentration of the mineral soil was best predicted by the combination of MAT, texture, and the $\mathrm{P}$ concentration of the parent material $\left(\mathrm{R}^{2}=0.25\right.$, Table 2$)$.

\section{Discussion}

\subsection{N stock increases strongly with increasing MAT}

Our finding that the $\mathrm{N}$ stock of the organic layer, increased more from $-2^{\circ} \mathrm{C}$ to $7.5^{\circ} \mathrm{C}$ MAT than the organic layer stock (Fig.1a and $\mathrm{b}$ ) indicates that the formation of the $\mathrm{N}$ stock is more sensitive to temperature than the formation of the organic matter stock. The reasons for the strong change in the $\mathrm{N}$ stock with MAT could potentially be, first, the higher $\mathrm{N}$ deposition towards the south/southwest of Sweden that enriches the organic layer in South/Southwest Sweden with N. Second, it could potentially be that the rate with which $\mathrm{N}$ is taken up by trees increases with decreasing MAT, leading to $\mathrm{N}$ depletion of the organic layer at sites with low MAT. Third, it might be that $\mathrm{N}_{2}$ fixation decreases strongly with decreasing MAT.

Atmospheric $\mathrm{N}$ deposition is well known to be an important $\mathrm{N}$ input in forest ecosystems in the south of Sweden (Akselsson et al., 2008, Högberg et al., 2017; Yu et al., 2018). However, our finding that $\mathrm{N}$ deposition was only loosely related to the $\mathrm{N}$ stock of the organic layer (Fig. 2c) suggests that $\mathrm{N}$ deposition only explains a small part of the increase in the $\mathrm{N}$ stock with increasing MAT. Concerning the second potential explanation it needs to be considered that the stem growth rate of trees decreased with MAT (Fig. 2d). Thus, the potential explanation that the organic layer N stock is decreased by a factor of 7.5 due to high tree $\mathrm{N}$ uptake in the forest with the lowest MAT and lowest tree stem growth rate compared to forests with the highest MAT and growth rate is rather questionable.

It seems rather likely that the increase in the organic layer $\mathrm{N}$ stock with increasing MAT is related with an increase in $\mathrm{N}_{2}$ fixation with increasing MAT. Rates of $\mathrm{N}_{2}$ fixation can be as high as $4 \mathrm{~kg} \mathrm{~N}^{-1} \mathrm{yr}^{-1}$ in boreal ecosystems (DeLuca et al., 2002; Lagerström et al., 2007; DeLuca et al., 2008; Gundale et al., 2010), which is a larger N input than atmospheric N deposition

260 in most boreal areas (Gundale et al., 2011) and in the forests studied here. $\mathrm{N}_{2}$ fixation is known to depend strongly on temperature in temperate and boreal ecosystems (Sorensen et al., 2011; Gundale et al., 2012; Rousk et al., 2013). Therefore, it 
https://doi.org/10.5194/bg-2021-346

Preprint. Discussion started: 22 December 2021

(c) Author(s) 2021. CC BY 4.0 License.

\section{(c) (i)}

seems likely that fact that the $\mathrm{N}$ stock of the organic layer increased more strongly with increasing MAT than the organic layer stock is related to the temperature-dependence of $\mathrm{N}_{2}$ fixation. Most studies that explored the temperature-dependence in high latitudinal ecosystems focused on arctic heath ecosystems (for exceptions see Gundale et al., 2012; Rousk et al., 2013), and explored the temperature-dependencies of $\mathrm{N}_{2}$ fixation in short-term incubation experiments, rather than natural gradients of MAT. Future research should fill this gap and explore the temperature-dependence of $\mathrm{N}_{2}$ fixation in forest soils along MAT gradients to investigate to which extent temperature-dependence of $\mathrm{N}_{2}$ fixation explains the change in $\mathrm{N}$ stocks along the MAT gradient observed here. Our results are largely in accordance with Callesen et al. (2007) who studied 198 forest soils in North Europe and reported that the $\mathrm{N}$ stock of the total soil profiles (organic layer plus uppermost $100 \mathrm{~cm}$ of the mineral soil) was positively correlated with MAT. Furthermore, our finding that the C:N ratio tended to decrease with increasing MAT (Supplement Fig. S1) is in accordance with a recent study on the organic layer C:N ratio in Swedish and German forests (Högberg et al., 2021).

\subsection{Organic layer N:P ratio decreases with increasing MAT}

275 Our finding that the organic layer N:P ratio increased with increasing MAT (Fig. 2f) indicates that P is not incorporated into the organic layer in a constant ratio with $\mathrm{N}$ across all temperature regimes. The reason for the change in the $\mathrm{N}: \mathrm{P}$ ratio with MAT could be a similar change in the N:P ratio of the plant litter inputs. This is supported by Akselsson et al. (2015) showing that the N:P ratio of pine and spruce needles was substantially larger in South/Southwest Sweden than in middle and North Sweden. This is further supported by studies about European forests reporting that the foliage N:P ratio decreases with increasing $\mathrm{N}$ inputs, because trees do not take up enough $\mathrm{P}$ to balance the high $\mathrm{N}$ availability (Flückiger and Braun, 1998; Braun et al. 2010; Talkner et al. 2015, Jonard et al., 2015). Further, it has was suggested in modelling exercises that high $\mathrm{N}$ inputs can lead to P limitation in south Swedish forests (Akselsson et al., 2008; Yu et al., 2018), resulting in increased needle $\mathrm{N}: \mathrm{P}$ ratios (Yu et al., 2018). Changes in foliage N:P ratio with MAT likely translate into similar changes in the N:P ratio of the organic layer. The reason why $\mathrm{P}$ is not incorporated into the plant biomass in a constant ratio with $\mathrm{N}$ across all temperature regimes is likely that $\mathrm{P}$ availability limits $\mathrm{P}$ uptake at sites with high $\mathrm{N}$ availability. This is supported by studies showing that despite the young age of Swedish forest soils, a relatively large proportion of the soil $\mathrm{P}$ is adsorbed to $\mathrm{Fe}$ and $\mathrm{Al}$ oxides (Giesler et al., 2002; Tuyishime et al., 2022). In contrast, latitude-dependent differences in dominant tree species (i.e., more deciduous forests in the South) do not seem to contribute to the change in the N:P ratio with MAT since there were no substantial differences in the N:P ratio of the organic layer between different forests dominated by different tree species (Fig. S2a).

\subsection{Organic matter stoichiometry varies with tree species, even in the subsoil}

We found that the $\mathrm{C}: \mathrm{N}$ and $\mathrm{C}: \mathrm{P}$ ratios of the organic layer were higher in pine forests than in forests dominated by other tree species, and a very similar difference in the $\mathrm{C}: \mathrm{N}$ ratio between forests dominated by different tree species was still observed in the mineral soil in a depth of 55-65 cm (Fig. 3). The differences in element ratios of the organic layer are likely derived 
https://doi.org/10.5194/bg-2021-346

Preprint. Discussion started: 22 December 2021

(c) Author(s) 2021. CC BY 4.0 License.

\section{(c) (i)}

from differences in the $\mathrm{C}: \mathrm{N}$ and $\mathrm{C}: \mathrm{P}$ ratio of the leaf/needle litter, since particularly the $\mathrm{C}: \mathrm{N}$ ratios of the organic layer are closely associated with the element ratios of the plant leaf/needle litter in Swedish forest soils (Ladanai et al., 2010). Similarly in the mineral soil, the differences in the $\mathrm{C}: \mathrm{N}$ ratio between forests dominated by different tree species are likely also due to the difference in the C:N ratio of the leaf and root litter and the litter layer (Cotrufo et al., 2013; Zechmeister-Boltenstern et al., 2015; Spohn and Chodak, 2015). In addition, the relatively low C:N ratio in the mineral soil in spruce forests compared to pine forests might also partially result from the fact that the spruce forests tended to have a slightly finer texture (Supplement Fig. S5c), which is associated with lower C:N ratios (Fig. 4d, see discussion below). This is in accordance with Stendahl et al. (2010) showing that in Swedish forests, spruce tends to grow in more fertile soils than pine. Further, we cannot exclude that differences in former land use (Goodale and Aber, 2001) or the depth of the groundwater table also affect the mineral soil C:N ratio, although at least the former seems unlikely given that the mean stand age of the forests was 113 years. Furthermore, some of the pine forest had extremely high $\mathrm{C}: \mathrm{N}$ and $\mathrm{C}: \mathrm{P}$ ratios, which might be due to charcoal in the soils which is likely more abundant in pine forests than in other forests due to more frequent fires (Zacckrisson, 1977). Previous studies also reported a very high $\mathrm{C}: \mathrm{N}$ ratio in the organic layer and the uppermost $\mathrm{cm}$ of the miner soil in pine forests compared to other forests in Europe (Vesterdal and Raulund-Rasmussen, 1998; Vesterdal et al., 2008; Hansson et al. 2011; Cools et al. 2014). However, this is the first study to show that this difference in the $\mathrm{C}: \mathrm{N}$ ratio between forest dominated by different tree species is also visible in the mineral subsoil, in a depth of $55-65 \mathrm{~cm}$, to our knowledge.

The higher C:P ratio of the organic layer observed for pine forests than for all other forests is very likely also related to differences in the stoichiometry of the plant litter inputs. Our result that the C:P ratio of the organic layer was higher in pine forests than in all other forests is in accordance with similar observations of the difference in the organic layer C:P ratio between pine and spruce forests (Vesterdal and Raulund-Rasmussen, 1998; Ladanai et al., 2010). The reason why we found

315 no substantial differences in the C:OP ratio in the mineral soil between forests dominated by different tree species (Fig. 3f) is that the concentration of OP in the mineral soil was strongly affected by texture (Fig. 4c), more strongly than the $\mathrm{N}$ concentration (Fig. 4b), as we will discuss in the following.

\subsection{Organic $P$ and $N$ contents are high in fine-textured soils}

320 The concentrations of $\mathrm{C}, \mathrm{N}$, and P were higher in fine-textured soils than in coarse-textured soils. The reason for this is very likely the higher charge density of fine-textured than of coarse-textured soils that allows a large number of organic compounds to adsorb to changed mineral surfaces, which protects them against microbial decomposition through steric hindrance (Lützow et al., 2006, Kögel-Knabner et al., 2008, Kleber et al., 2015). Our results are in accordance with previous studies showing that the capacity of soils to store OM is largely determined by the proportion of fine mineral particles with high surface area and high charge density, such as for example, phyllosilicates and Fe and Al oxides (Oades, 1988; Mayer, 1994; Christensen, 1996; Hassink, 1997). Sorption of OM to mineral surfaces is one of the most important processes that slows down the decomposition 
https://doi.org/10.5194/bg-2021-346

Preprint. Discussion started: 22 December 2021

(c) Author(s) 2021. CC BY 4.0 License.

\section{(c) (i)}

of organic matter in soils (Lützow et al. 2006; Kleber et al. 2007; Kögel-Knabner et al. 2008), and very likely leads to enrichment of $\mathrm{OM}$ in the fine-textured forest soils studied here.

Our finding that the enrichment in fine-textured soils (compared to coarse-textured soils) increased in the order $\mathrm{C}<\mathrm{N}<\mathrm{OP}$, indicates that the capacity to compete for sorption sites is highest for P-containing compounds, and higher for N-containing compounds than for $\mathrm{N}$ - and P-free compounds. This interpretation is supported by studies demonstrating that phosphorylated organic compounds have a larger capacity to compete for binding sites in soils than non-phosphorylated organic compounds (Afif et al., 1995; Franssson and Jones, 2007; Schneider et al., 2010). Sorption to mineral surfaces makes OP compounds likely more persistent in soil than non-phosphorylated organic compounds (Spohn et al., 2020a, b). Similarly, a large part of N is present in SOM in the form of charged nitrate or ammonium moieties, for example in peptides that can adsorb to charged surfaces, which decreases their decomposition rate (Knicker et al., 1993; Jones and Hodges, 1999; Miltner et al., 2009; Kopittke et al., 2018). Thus, the high capacity of $\mathrm{N}$ - and P-containing organic compounds to adsorb to changed surfaces in soils is likely the reason why $\mathrm{N}$, and particularly $\mathrm{OP}$ has higher concentrations in the fine-textured soils compared to the coarse-textured soils than C.

340 The effect of texture was also visible is the organic layer, as the fine-textured soils had higher litter $\mathrm{N}$ stocks than the coarsetextured soils (Fig. 4f). The reason for this is most likely that fine-textured soils are commonly formed from nutrient-rich minerals, which causes high plant productivity and $\mathrm{N}_{2}$ fixation, resulting in high litter layer $\mathrm{N}$ concentrations in fine-textured soils compared to coarse-textured soils.

\section{$345 \quad 4.5 \mathrm{P}$ and $\mathrm{K}$ contents are negatively related to the organic layer stock}

We found that the organic matter stock was negatively related with the concentration of exchangeable K (Fig. 5a and b). The reason for this negative correlation is likely that $\mathrm{K}$ leaches fast from plant litter (Osono and Takeda, 2004; Schlesinger et al., 2021), and thus, thin organic layers that consist largely of relatively young organic matter have a higher K concentration than massive organic layers that mostly consist of old, K-poor organic matter. In addition, it could be that there is a relatively high contribution of fine-woody debris, which is K-poor, to the more massive organic layers. The relationship found here between the $\mathrm{K}$ concentration of the organic layer and the organic matter stock (Figs. 4 and b) is in agreement with the relationship reported by Stendahl et al. (2017) between the C stock of the organic layer and both its K and Mn concentration. Furthermore, we also observed a similar relationship between the organic layer stock and its $P$ concentration (Fig. $5 \mathrm{c}$ and d), indicating that $\mathrm{P}$ follows a similar dynamic as $\mathrm{K}$. The reasons for this could be fast leaching of $\mathrm{P}$ or a higher contribution of fine woody debris, which is P-poor (Spohn et al., 2020b) to the organic layer in forests with high organic layer stock.

\subsection{Conclusion}

We found that the $\mathrm{N}$ stock of the organic layer increased more with MAT than the organic layer stock, which is likely due to the temperature-dependence of $\mathrm{N}_{2}$ fixation. Against our first hypothesis, we observed that the N:P ratio of the organic layer 
https://doi.org/10.5194/bg-2021-346

Preprint. Discussion started: 22 December 2021

(c) Author(s) 2021. CC BY 4.0 License.

(c) (i)

360 decreased substantially with increasing MAT, likely due to a decrease in the ratio of N:P availability with increasing MAT. Further, the C:OP ratio showed similar differences between forests dominated by different tree species as the C:N ratio in the organic layer, as hypothesized, however, not in the mineral soil. The reason for this is likely that the OP concentration was very strongly affected by texture in the mineral soil, and the concentration of OP was much higher in fine- than in coarsetextured soils. The difference in element concentrations between fine- and coarse-textured soils decreased in the order

$365 \mathrm{OP}>\mathrm{N}>\mathrm{C}$, in agreement with the third hypothesis. Taken together, the results show that the N:P ratio of the organic layer was most strongly related to MAT. Further, the C:N ratio was most strongly related to dominant tree species, even in the mineral subsoil. In contrast, the C:P ratio was only affected by dominant tree species in the organic layer, but the C:OP ratio in the mineral soil was hardly affected by tree species due to the strong effect of soil texture on the OP concentration.

\section{Code Availability}

The $\mathrm{R}$ code will be made publically available once the manuscript is accepted for publication, and can be obtained from the authors upon request before manuscript publication.

\section{Data availability}

All data will be made publically available once the manuscript is accepted for publication, and can be obtained from the authors upon request before manuscript publication.

\section{Author contributions}

380 MS designed the study, conducted the data analysis, and wrote the manuscript, JS leads the Swedish Forest Soil Inventory and contributed to the manuscript.

\section{Acknowledgments}

The authors thank all technical staff who conducted the sampling and chemical analyses, and particularly Oscar Skirfors for

385 conducting the $\mathrm{P}$ analyses. The Swedish Forest Soil Inventory is part of the national environmental monitoring commissioned by the Swedish Environmental Protection Agency.

\section{References}

Afif, E., Barron, V., \& Torrent, J. (1995). Organic matter delays but does not prevent phosphate sorption by Cerrado soils from 390 Brazil. Soil Science, 159(3), 207-211.

Akselsson, C. Karlsson, G.P., Karlsson P.E., \& Ahlstrand, J. (2015) Miljöövervakning på Obsytorna 1984-2013, Skogsstyrelsen, p. 142 
https://doi.org/10.5194/bg-2021-346

Preprint. Discussion started: 22 December 2021

(c) Author(s) 2021. CC BY 4.0 License.

(c) (i)

Akselsson, C., Westling, O., Alveteg, M., Thelin, G., Fransson, A. M., \& Hellsten, S. (2008). The influence of N load and harvest intensity on the risk of P limitation in Swedish forest soils. Science of the Total Environment, 404(2-3), 284-289.

Bradshaw, C. J., \& Warkentin, I. G. (2015). Global estimates of boreal forest carbon stocks and flux. Global and Planetary Change, 128, 24-30.

Braun, S., Thomas, V. F., Quiring, R., \& Flückiger, W. (2010). Does nitrogen deposition increase forest production? The role of phosphorus. Environmental Pollution, 158(6), 2043-2052.

Callesen, I., Raulund-Rasmussen, K., Westman, C. J., \& Tau-Strand, L. (2007). Nitrogen pools and C: N ratios in well-drained

400 Nordic forest soils related to climate and soil texture. Boreal Environmental Research 12, 681-692.

Christensen, B. T. (2001). Physical fractionation of soil and structural and functional complexity in organic matter turnover. European Journal of Soil Science, 52(3), 345-353.

Cools, N., Vesterdal, L., De Vos, B., Vanguelova, E., \& Hansen, K. (2014). Tree species is the major factor explaining C: N ratios in European forest soils. Forest Ecology and Management, 311, 3-16.

405 Cotrufo, M. F., Wallenstein, M. D., Boot, C. M., Denef, K., \& Paul, E. (2013). The Microbial Efficiency-Matrix Stabilization (MEMS) framework integrates plant litter decomposition with soil organic matter stabilization: do labile plant inputs form stable soil organic matter?. Global Change Biology, 19(4), 988-995.

DeLuca, T. H., Zackrisson, O., Gundale, M. J., \& Nilsson, M. C. (2008). Ecosystem feedbacks and nitrogen fixation in boreal forests. Science, 320(5880), 1181-1181.

410 DeLuca, T. H., Zackrisson, O., Nilsson, M. C., \& Sellstedt, A. (2002). Quantifying nitrogen-fixation in feather moss carpets of boreal forests. Nature, 419(6910), 917-920.

Feng, W., Plante, A. F., \& Six, J. (2013). Improving estimates of maximal organic carbon stabilization by fine soil particles. Biogeochemistry, 112(1), 81-93.

Flückiger, W., \& Braun, S. (1998). Nitrogen deposition in Swiss forests and its possible relevance for leaf nutrient status, 415 parasite attacks and soil acidification. Environmental Pollution, 102(1), 69-76.

Fransson, A. M., \& Jones, D. L. (2007). Phosphatase activity does not limit the microbial use of low molecular weight organicP substrates in soil. Soil Biology and Biochemistry, 39(5), 1213-1217.

Giesler, R., Petersson, T., \& Högberg, P. (2002). Phosphorus limitation in boreal forests: effects of aluminum and iron accumulation in the humus layer. Ecosystems, 5(3), 300-314.

420 Goodale, C. L., \& Aber, J. D. (2001). The long-term effects of land-use history on nitrogen cycling in northern hardwood forests. Ecological Applications, 11(1), 253-267.

Gundale, M. J., Deluca, T. H., \& Nordin, A. (2011). Bryophytes attenuate anthropogenic nitrogen inputs in boreal forests. Global Change Biology, 17(8), 2743-2753.

Gundale, M. J., Nilsson, M., Bansal, S., \& Jäderlund, A. (2012). The interactive effects of temperature and light on biological nitrogen fixation in boreal forests. New Phytologist, 194(2), 453-463. 
https://doi.org/10.5194/bg-2021-346

Preprint. Discussion started: 22 December 2021

(c) Author(s) 2021. CC BY 4.0 License.

(c) (i)

Gundale, M. J., Wardle, D. A., \& Nilsson, M. C. (2010). Vascular plant removal effects on biological N fixation vary across a boreal forest island gradient. Ecology, 91(6), 1704-1714.

Hansson, K., Olsson, B. A., Olsson, M., Johansson, U., \& Kleja, D. B. (2011). Differences in soil properties in adjacent stands of Scots pine, Norway spruce and silver birch in SW Sweden. Forest Ecology and Management, 262(3), 522-530.

Hassink, J. (1997). The capacity of soils to preserve organic C and N by their association with clay and silt particles. Plant and Soil, 191(1), 77-87.

Heuck, C., Smolka, G., Whalen, E. D., Frey, S., Gundersen, P., Moldan, F., ... \& Spohn, M. (2018). Effects of long-term nitrogen addition on phosphorus cycling in organic soil horizons of temperate forests. Biogeochemistry, 141(2), 167-181.

Hounkpatin, K. O., Stendahl, J., Lundblad, M., \& Karltun, E. (2021). Predicting the spatial distribution of soil organic carbon stock in Swedish forests using a group of covariates and site-specific data. SOIL, 7(2), 377-398.

Högberg, P., Näsholm, T., Franklin, O., \& Högberg, M. N. (2017). Tamm Review: On the nature of the nitrogen limitation to plant growth in Fennoscandian boreal forests. Forest Ecology and Management, 403, 161-185.

Högberg, P., Wellbrock, N., Högberg, M. N., Mikaelsson, H., \& Stendahl, J. (2021). Large differences in plant nitrogen supply in German and Swedish forests-Implications for management. Forest Ecology and Management, 482, 118899.

440 Jonard, M., Fürst, A., Verstraeten, A., Thimonier, A., Timmermann, V., Potočić, N., ... \& Rautio, P. (2015). Tree mineral nutrition is deteriorating in Europe. Global Change Biology, 21(1), 418-430.

Jones, D. L., \& Hodge, A. (1999). Biodegradation kinetics and sorption reactions of three differently charged amino acids in soil and their effects on plant organic nitrogen availability. Soil Biology and Biochemistry, 31(9), 1331-1342.

Kleber, M., Eusterhues, K., Keiluweit, M., Mikutta, C., Mikutta, R., \& Nico, P. S. (2015). Mineral-organic associations:

445 formation, properties, and relevance in soil environments. Advances in Agronomy, 130, 1-140.

Kleber, M., Sollins, P., \& Sutton, R. (2007). A conceptual model of organo-mineral interactions in soils: self-assembly of organic molecular fragments into zonal structures on mineral surfaces. Biogeochemistry, 85(1), 9-24.

Knicker, H., Fründ, R., \& Lüdemann, H. D. (1993). The chemical nature of nitrogen in native soil organic matter. Naturwissenschaften, 80(5), 219-221.

450 Kögel-Knabner, I., Guggenberger, G., Kleber, M., Kandeler, E., Kalbitz, K., Scheu, S., ... \& Leinweber, P. (2008). Organomineral associations in temperate soils: Integrating biology, mineralogy, and organic matter chemistry. Journal of Plant Nutrition and Soil Science, 171(1), 61-82.

Kopittke, P. M., Hernandez-Soriano, M. C., Dalal, R. C., Finn, D., Menzies, N. W., Hoeschen, C., \& Mueller, C. W. (2018). Nitrogen-rich microbial products provide new organo-mineral associations for the stabilization of soil organic matter. Global 455 Change Biology, 24(4), 1762-1770.

Ladanai, S., Ågren, G. I., \& Olsson, B. A. (2010). Relationships between tree and soil properties in Picea abies and Pinus sylvestris forests in Sweden. Ecosystems, 13(2), 302-316. 
https://doi.org/10.5194/bg-2021-346

Preprint. Discussion started: 22 December 2021

(c) Author(s) 2021. CC BY 4.0 License.

(c) (i)

Lützow, M. V., Kögel-Knabner, I., Ekschmitt, K., Matzner, E., Guggenberger, G., Marschner, B., \& Flessa, H. (2006). Stabilization of organic matter in temperate soils: mechanisms and their relevance under different soil conditions-a review.

European Journal of Soil Science, 57(4), 426-445.

Mayer, L. M., Schick, L. L., Hardy, K. R., Wagai, R., \& McCarthy, J. (2004). Organic matter in small mesopores in sediments and soils. Geochimica et Cosmochimica Acta, 68(19), 3863-3872.

Miltner, A., Kindler, R., Knicker, H., Richnow, H. H., \& Kästner, M. (2009). Fate of microbial biomass-derived amino acids in soil and their contribution to soil organic matter. Organic Geochemistry, 40(9), 978-985.

465 Murphy, J. A. M. E. S., \& Riley, J. P. (1962). A modified single solution method for the determination of phosphate in natural waters. Analytica Chimica Acta, 27, 31-36.

Oades, J. M. (1988). The retention of organic matter in soils. Biogeochemistry, 5(1), 35-70.

Olsson, M., Rosén, K., \& Melkerud, P. A. (1993). Regional modelling of base cation losses from Swedish forest soils due to whole-tree harvesting. Applied Geochemistry, 8, 189-194.

Osono, T., \& Takeda, H. (2004). Potassium, calcium, and magnesium dynamics during litter decomposition in a cool temperate forest. Journal of Forest Research, 9(1), 23-31.

Pansu, M., \& Gautheyrou, J. (2006). Handbook of soil analysis: mineralogical, organic and inorganic methods. Springer Science \& Business Media.

R Core Team, 2003. A Language and Environment for Statistical Computing R Foundation for Statistical Computing. Austria, 475 Vienna.

Ranneby, B., Cruse, T., Hägglund, B., Jonasson, H., \& Swärd, J. (1987). Designing a new national forest survey for Sweden. Studia Forestalia Suecica 177.

Rousk, K., Jones, D. L., \& DeLuca, T. H. (2013). Moss-cyanobacteria associations as biogenic sources of nitrogen in boreal forest ecosystems. Frontiers in Microbiology, 4, 150.

480 Saunders, W. M. H., \& Williams, E. G. (1955). Observations on the determination of total organic phosphorus in soils. Journal of Soil Science, 6(2), 254-267.

Schlesinger, W. H. (2021). Some thoughts on the biogeochemical cycling of potassium in terrestrial ecosystems. Biogeochemistry, 154(2), 427-432.

Schneider, M. P. W., Scheel, T., Mikutta, R., Van Hees, P., Kaiser, K., \& Kalbitz, K. (2010). Sorptive stabilization of organic matter by amorphous Al hydroxide. Geochimica et Cosmochimica Acta, 74(5), 1606-1619.

Sorensen, P. L., \& Michelsen, A. (2011). Long-term warming and litter addition affects nitrogen fixation in a subarctic heath. Global Change Biology, 17(1), 528-537.

Spohn, M. (2020a). Phosphorus and carbon in soil particle size fractions: A synthesis. Biogeochemistry, 147(3), 225-242.

Spohn, M. (2020b). Increasing the organic carbon stocks in mineral soils sequesters large amounts of phosphorus. Global 490 Change Biology, 26(8), 4169-4177. 
https://doi.org/10.5194/bg-2021-346

Preprint. Discussion started: 22 December 2021

(c) Author(s) 2021. CC BY 4.0 License.

(c) (i)

Spohn, M., \& Chodak, M. (2015). Microbial respiration per unit biomass increases with carbon-to-nutrient ratios in forest soils. Soil Biology and Biochemistry, 81, 128-133.

Stendahl, J., Berg, B., \& Lindahl, B. D. (2017). Manganese availability is negatively associated with carbon storage in northern coniferous forest humus layers. Scientific Reports, 7(1), 1-6.

495 Stendahl, J., Johansson, M. B., Eriksson, E., Nilsson, Å., \& Langvall, O. (2010). Soil organic carbon in Swedish spruce and pine forests-differences in stock levels and regional patterns. Silva Fennica, 44(1), 5-21.

Tau-Strand, L., Callesen, I., Dalsgaard, L., \& de Wit, H. A. (2016). Carbon and nitrogen stocks in Norwegian forest soilsthe importance of soil formation, climate, and vegetation type for organic matter accumulation. Canadian Journal of Forest Research, 46(12), 1459-1473.

500 Talkner, U., Meiwes, K. J., Potočić, N., Seletković, I., Cools, N., De Vos, B., \& Rautio, P. (2015). Phosphorus nutrition of beech (Fagus sylvatica L.) is decreasing in Europe. Annals of Forest Science, 72(7), 919-928.

Tipping, E., Somerville, C. J., \& Luster, J. (2016). The C: N: P: S stoichiometry of soil organic matter. Biogeochemistry, 130(1), 117-131.

Tuyishime, J. M., Adediran, G. A., Olsson, B. A., Spohn, M., Hillier, S., Klysubun, W., \& Gustafsson, J. P. (2022). Phosphorus

505 abundance and speciation in acid forest Podzols-Effect of postglacial weathering. Geoderma, 406, 115500.

Vejre, H., Callesen, I., Vesterdal, L., \& Raulund-Rasmussen, K. (2003). Carbon and nitrogen in Danish forest soils—contents and distribution determined by soil order. Soil Science Society of America Journal, 67(1), 335-343.

Vesterdal, L., \& Raulund-Rasmussen, K. (1998). Forest floor chemistry under seven tree species along a soil fertility gradient. Canadian Journal of Forest Research, 28(11), 1636-1647.

510 Vesterdal, L., Schmidt, I. K., Callesen, I., Nilsson, L. O., \& Gundersen, P. (2008). Carbon and nitrogen in forest floor and mineral soil under six common European tree species. Forest Ecology and Management, 255(1), 35-48.

Vincent, A. G., Vestergren, J., Gröbner, G., Persson, P., Schleucher, J., \& Giesler, R. (2013). Soil organic phosphorus transformations in a boreal forest chronosequence. Plant and Soil, 367(1), 149-162.

Williams, E. G., \& Saunders, W. M. H. (1956). Distribution of phosphorus in profiles and particle-size fractions of some

515 Scottish soils. Journal of Soil Science, 7(1), 90-109.

Yu, L., Zanchi, G., Akselsson, C., Wallander, H., \& Belyazid, S. (2018). Modeling the forest phosphorus nutrition in a southwestern Swedish forest site. Ecological Modelling, 369, 88-100.

Zachrisson, O. (1977). Influence of forest fires on the North Swedish boreal forest. Oikos, 29, 22-32.

Zechmeister-Boltenstern, S., Keiblinger, K. M., Mooshammer, M., Peñuelas, J., Richter, A., Sardans, J., \& Wanek, W. (2015).

520 The application of ecological stoichiometry to plant-microbial-soil organic matter transformations. Ecological Monographs, 85(2), 133-155. 
https://doi.org/10.5194/bg-2021-346

Preprint. Discussion started: 22 December 2021

(c) Author(s) 2021. CC BY 4.0 License.

\section{Tables}

525 Table 1: Results of the correlation analysis $\left(\mathrm{R}^{2}, \mathrm{p}\right.$ value) for the total mass of the organic layer as well as organic carbon (C), nitrogen $(\mathrm{N})$ and organic phosphorus $(\mathrm{OP})$ stocks of the organic layer and contents in the mineral soil as dependent variable, and latitude, mean annual temperature (MAT), mean annual precipitation (MAP), and the log-transformed N deposition as independent variable in 309 Swedish forest soils $(n=309)$.

\begin{tabular}{lllll}
\hline & $\begin{array}{l}\text { Latitude } \\
\left({ }^{\circ}\right)\end{array}$ & $\begin{array}{l}\text { MAT } \\
\left({ }^{\circ} \mathrm{C}\right)\end{array}$ & $\begin{array}{l}\text { MAP } \\
(\mathrm{mm})\end{array}$ & $\begin{array}{l}\text { Log N deposition } \\
\left(\mathrm{kg} \mathrm{ha}^{-1}\right)\end{array}$ \\
\hline Organic layer stock $\left(\mathrm{t} \mathrm{ha}{ }^{-1}\right)$ & $0.13, \mathrm{p}<0.001$ & $0.13, \mathrm{p}<0.001$ & $\mathrm{p}>0.05$ & $0.15, \mathrm{p}<0.001$ \\
C stock organic layer $\left(\mathrm{kg} \mathrm{ha}^{-1}\right)$ & $0.14, \mathrm{p}<0.001$ & $0.14, \mathrm{p}<0.001$ & $\mathrm{p}>0.05$ & $0.15, \mathrm{p}<0.001$ \\
$\mathrm{~N}$ stock organic layer $\left(\mathrm{kg} \mathrm{ha}^{-1}\right)$ & $0.22, \mathrm{p}<0.001$ & $0.23, \mathrm{p}<0.001$ & $\mathrm{p}>0.05$ & $0.26, \mathrm{p}<0.001$ \\
P stock organic layer $\left(\mathrm{kg} \mathrm{ha}^{-1}\right)$ & $0.08, \mathrm{p}<0.001$ & $0.10, \mathrm{p}<0.001$ & $\mathrm{p}>0.05$ & $0.10, \mathrm{p}<0.001$ \\
Molar C:N ratio organic layer & $0.08, \mathrm{p}<0.001$ & $0.08, \mathrm{p}<0.001$ & $0.02, \mathrm{p}<0.01$ & $0.11, \mathrm{p}<0.001$ \\
Molar C:P ratio organic layer & $0.03, \mathrm{p}<0.01$ & $0.03, \mathrm{p}<0.01$ & $\mathrm{p}>0.05$ & $0.03, \mathrm{p}<0.01$ \\
Molar N:P ratio organic layer & $0.36, \mathrm{p}<0.001$ & $0.36, \mathrm{p}<0.001$ & $0.06, \mathrm{p}<0.001$ & $0.40, \mathrm{p}<0.001$ \\
C concentration mineral soil $\left(\mathrm{g} \mathrm{kg}^{-1}\right)$ & $0.14, \mathrm{p}<0.001$ & $0.16, \mathrm{p}<0.001$ & $\mathrm{p}>0.05$ & $0.12, \mathrm{p}<0.001$ \\
N concentration mineral soil $\left(\mathrm{g} \mathrm{kg}^{-1}\right)$ & $0.10, \mathrm{p}<0.001$ & $0.12, \mathrm{p}<0.001$ & $\mathrm{p}>0.05$ & $0.08, \mathrm{p}<0.001$ \\
OP concentration mineral soil $\left(\mathrm{g} \mathrm{kg}^{-1}\right)$ & $\mathrm{p}>0.05$ & $\mathrm{p}>0.05$ & $\mathrm{p}>0.05$ & $\mathrm{p}>0.05$ \\
Molar C:N ratio mineral soil & $\mathrm{p}>0.05$ & $\mathrm{p}>0.05$ & $\mathrm{p}>0.05$ & $\mathrm{p}>0.05$ \\
Molar C:OP ratio mineral soil & $0.06, \mathrm{p}<0.001$ & $0.07, \mathrm{p}<0.001$ & $\mathrm{p}>0.05$ & $0.05, \mathrm{p}<0.001$ \\
Molar N:OP ratio mineral soil & $0.04, \mathrm{p}<0.001$ & $0.04, \mathrm{p}<0.001$ & $\mathrm{p}>0.05$ & $0.03, \mathrm{p}<0.001$
\end{tabular}


545 Table 2: Results of the multiple regression analysis $\left(\mathrm{R}^{2}, \mathrm{p}\right.$ value) for the total mass of the organic layer as well as organic carbon (C), nitrogen (N) and organic phosphorus (OP) stocks of the organic layer and contents in the mineral soil as dependent variable, and latitude, mean annual temperature (MAT), NTree, and the P content of the parent material (Pparent) as independent variable in 309 Swedish forest soils $(n=309)$. NTree has the value 1 for pine, 2 for mixed and spruce forests, and 3 for deciduous forests.

\begin{tabular}{lccc}
\hline & $\begin{array}{c}\text { MAT } \\
+ \text { Texture class }\end{array}$ & $\begin{array}{c}\text { MAT } \\
+ \text { Texture class } \\
+ \text { NTree }\end{array}$ & $\begin{array}{c}\text { MAT } \\
+ \text { Texture class } \\
+ \text { Pparent }\end{array}$ \\
\hline Organic layer stock $\left(\mathrm{t} \mathrm{ha}^{-1}\right)$ & $0.14, \mathrm{p}<0.001$ & $0.15, \mathrm{p}<0.001$ & - \\
C stock organic layer $\left(\mathrm{kg} \mathrm{ha}^{-1}\right)$ & $0.15, \mathrm{p}<0.001$ & $>0.05$ & - \\
N stock organic layer $\left(\mathrm{kg} \mathrm{ha}^{-1}\right)$ & $0.23, \mathrm{p}<0.001$ & $>0.05$ & - \\
P stock organic layer $\left(\mathrm{kg} \mathrm{ha}^{-1}\right)$ & $0.10, \mathrm{p}<0.001$ & $>0.05$ & $0.10, \mathrm{p}<0.001$ \\
Molar C:N ratio organic layer & $0.11, \mathrm{p}<0.001$ & $>0.05$ & - \\
Molar C:P ratio organic layer & $0.03, \mathrm{p}<0.05$ & $>0.05$ & $0.05, \mathrm{p}<0.01$ \\
Molar N:P ratio organic layer & $0.36, \mathrm{p}<0.001$ & $>0.05$ & $0.36, \mathrm{p}<0.001$ \\
C concentration mineral soil $\left(\mathrm{g} \mathrm{kg}^{-1}\right)$ & $0.20, \mathrm{p}<0.001$ & $0.21, \mathrm{p}<0.001$ & - \\
N concentration mineral soil $\left(\mathrm{g} \mathrm{kg}^{-1}\right)$ & $0.10, \mathrm{p}<0.001$ & $0.22, \mathrm{p}<0.001$ & - \\
OP concentration mineral soil $\left(\mathrm{g} \mathrm{kg}^{-1}\right)$ & $0.08, \mathrm{p}<0.001$ & $0.09, \mathrm{p}<0.001$ & $0.25, \mathrm{p}<0.01$ \\
Molar C:N ratio mineral soil & $0.05, \mathrm{p}<0.001$ & $0.13, \mathrm{p}<0.001$ & - \\
Molar C:OP ratio mineral soil & $0.08, \mathrm{p}<0.001$ & $0.08, \mathrm{p}<0.001$ & $0.08, \mathrm{p}<0.001$ \\
Molar N:OP ratio mineral soil & $0.04, \mathrm{p}<0.001$ & $0.04, \mathrm{p}<0.001$ & $0.04, \mathrm{p}<0.001$ \\
\hline
\end{tabular}


https://doi.org/10.5194/bg-2021-346

Preprint. Discussion started: 22 December 2021

(c) Author(s) 2021. CC BY 4.0 License.

(c) (1)

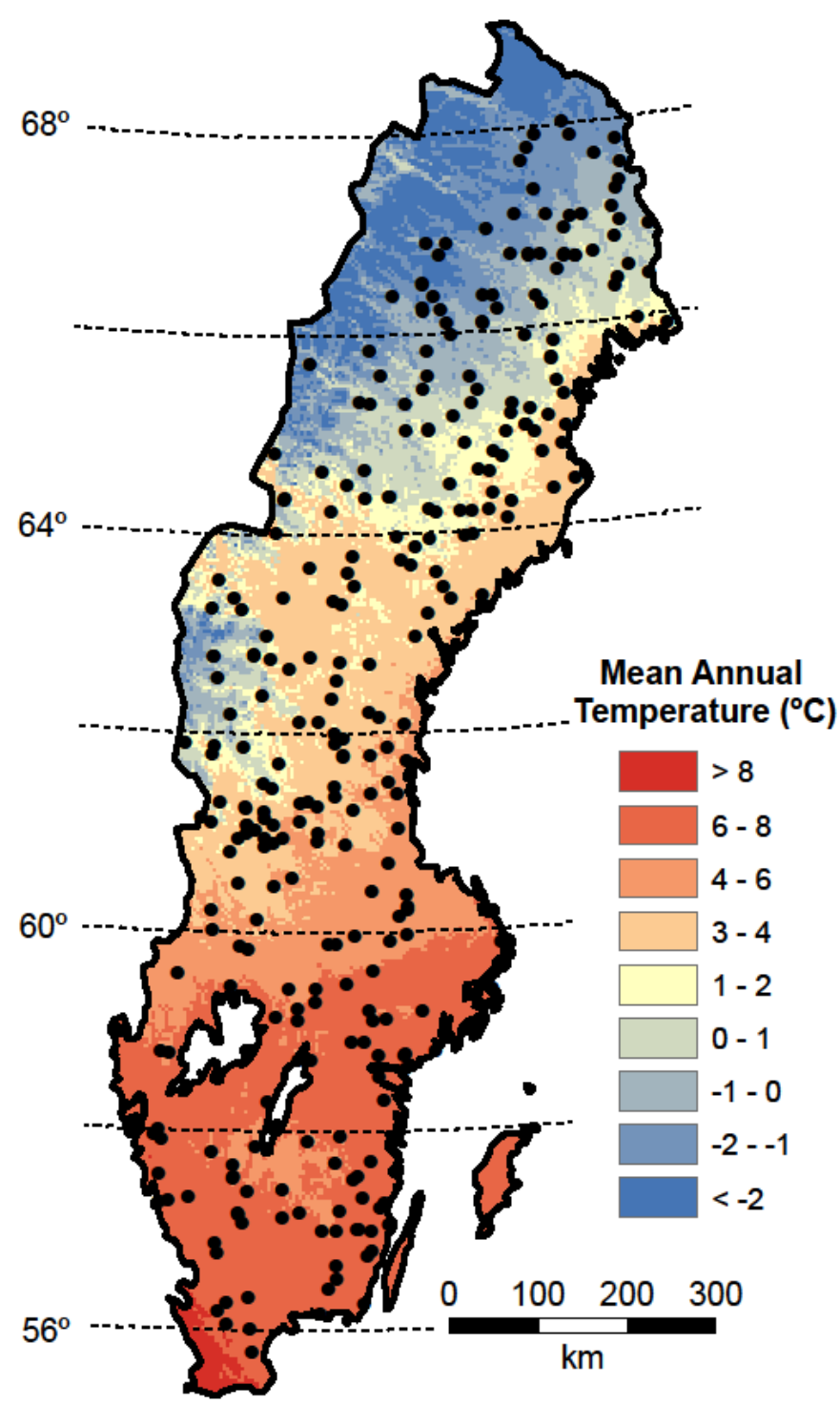

Figure 1: Map depicting mean annual temperature (MAP), latitude, and the plot locations (black dots). 

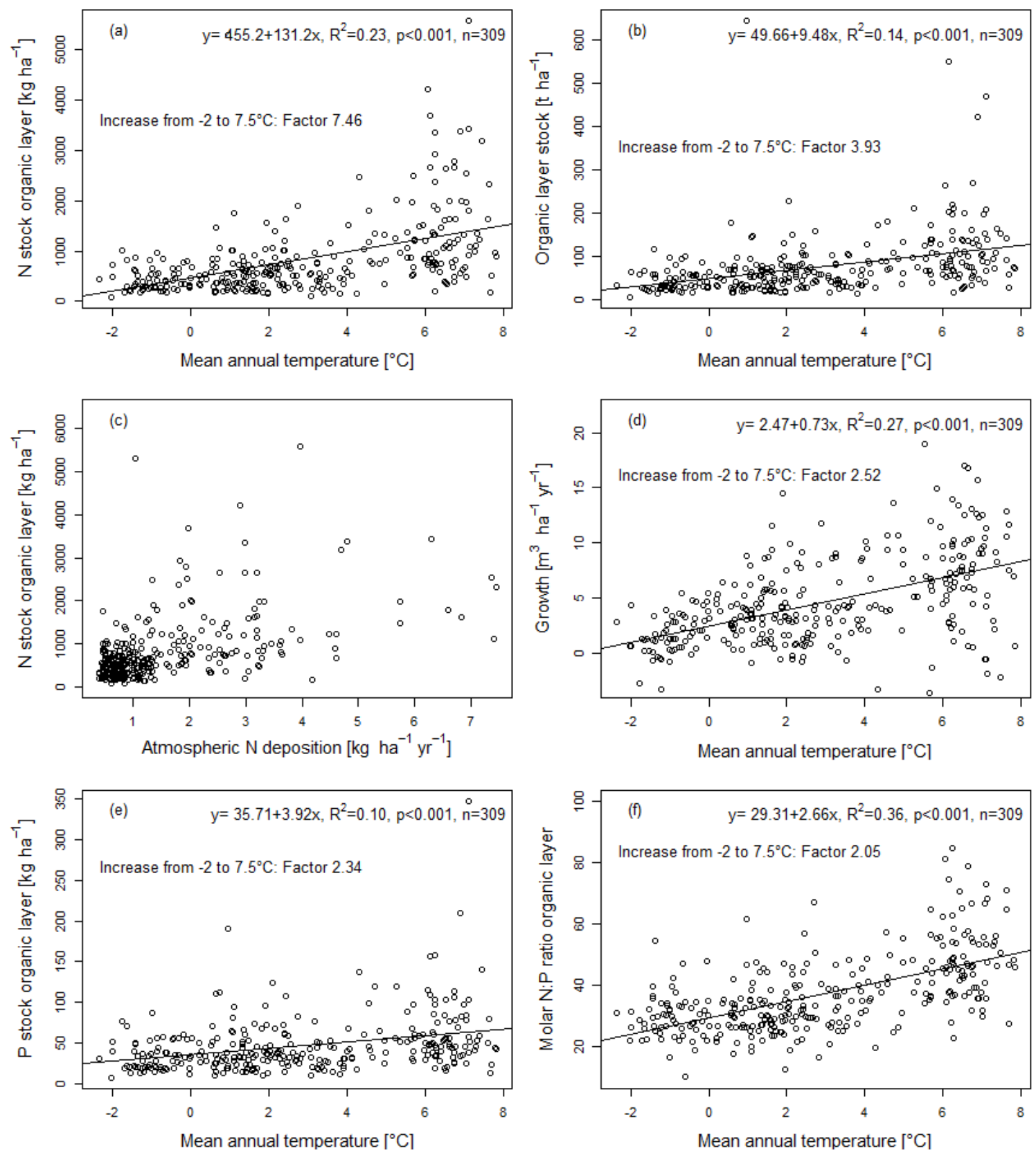

Figure 2: The nitrogen $(\mathrm{N})$ stock of the organic layer (a) and the organic layer stock (b) as a function of mean annual temperature together with the $\mathrm{N}$ tock of the organic layer as a function of $\mathrm{N}$ deposition (c) as well as tree stem growth (d), the $\mathrm{P}$ stock of the organic layer (e), and the molar nitrogen-to-phosphorus (N:P) ratio of the organic layer (f) as a function of mean annual temperature in 309 Swedish forest soils with a stand age $>60$ years. 

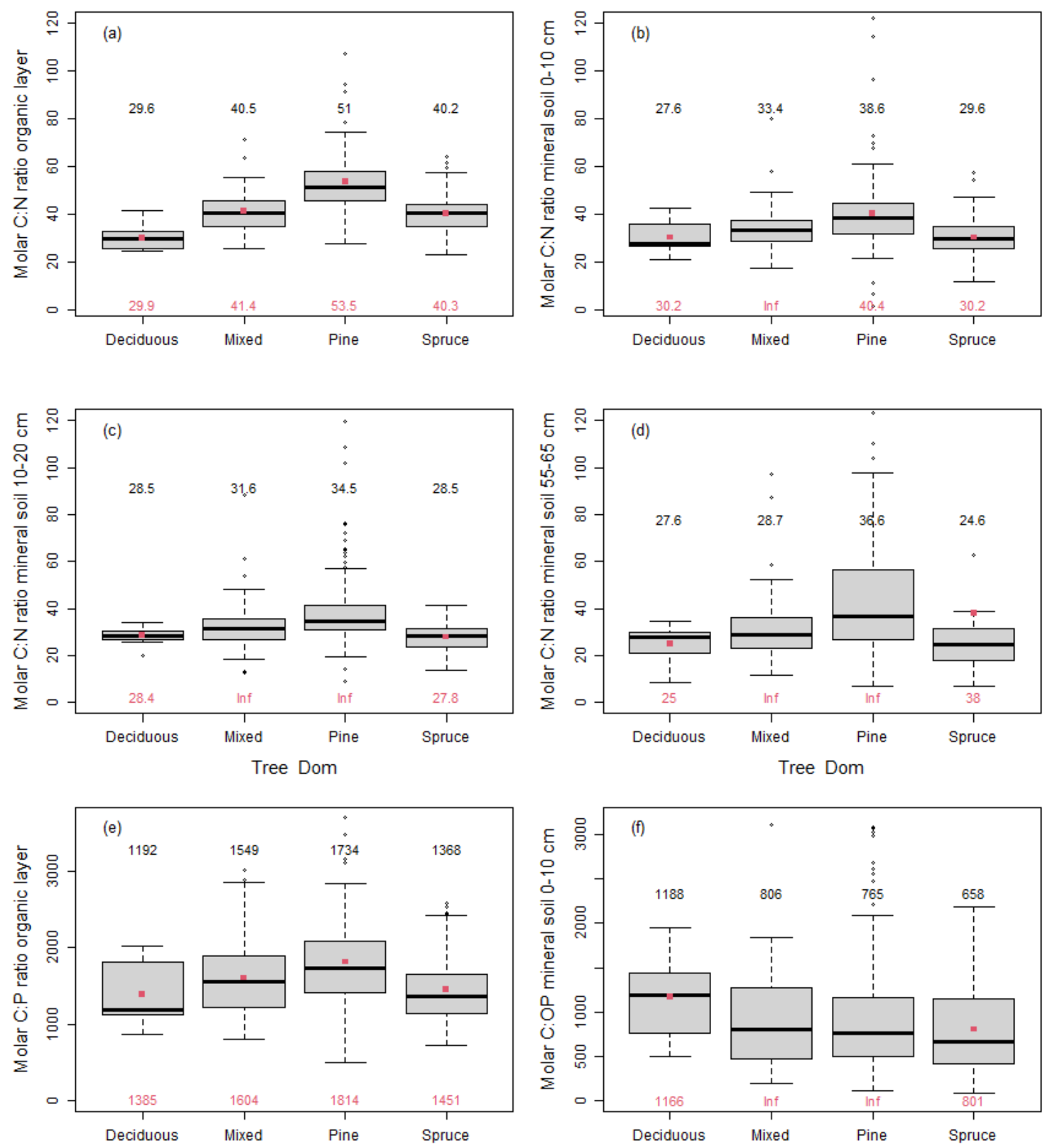

570 Figure 3: Molar carbon-to-nitrogen $(\mathrm{C}: \mathrm{N})$ ratio of the organic layer (a) and the mineral soil in $0-10 \mathrm{~cm}$ depth (b), 10-20 cm depth (c), and 55-65 cm depth (d) as well as the molar carbon-to-phosphorus (C:P) ratio of the organic layer (e) and the molar carbon-to-organic phosphorus (C:OP) ratio in the mineral soil in 0-10 cm (f) depending on the dominant tree species (deciduous $\mathrm{n}=10$, mixed $\mathrm{n}=67$, pine $\mathrm{n}=144$, and spruce $\mathrm{n}=88$ ). Please notice that mixed refers to mixed pine and spruce. Black numbers give the median, red dots and red numbers depict the arithmetic mean. 

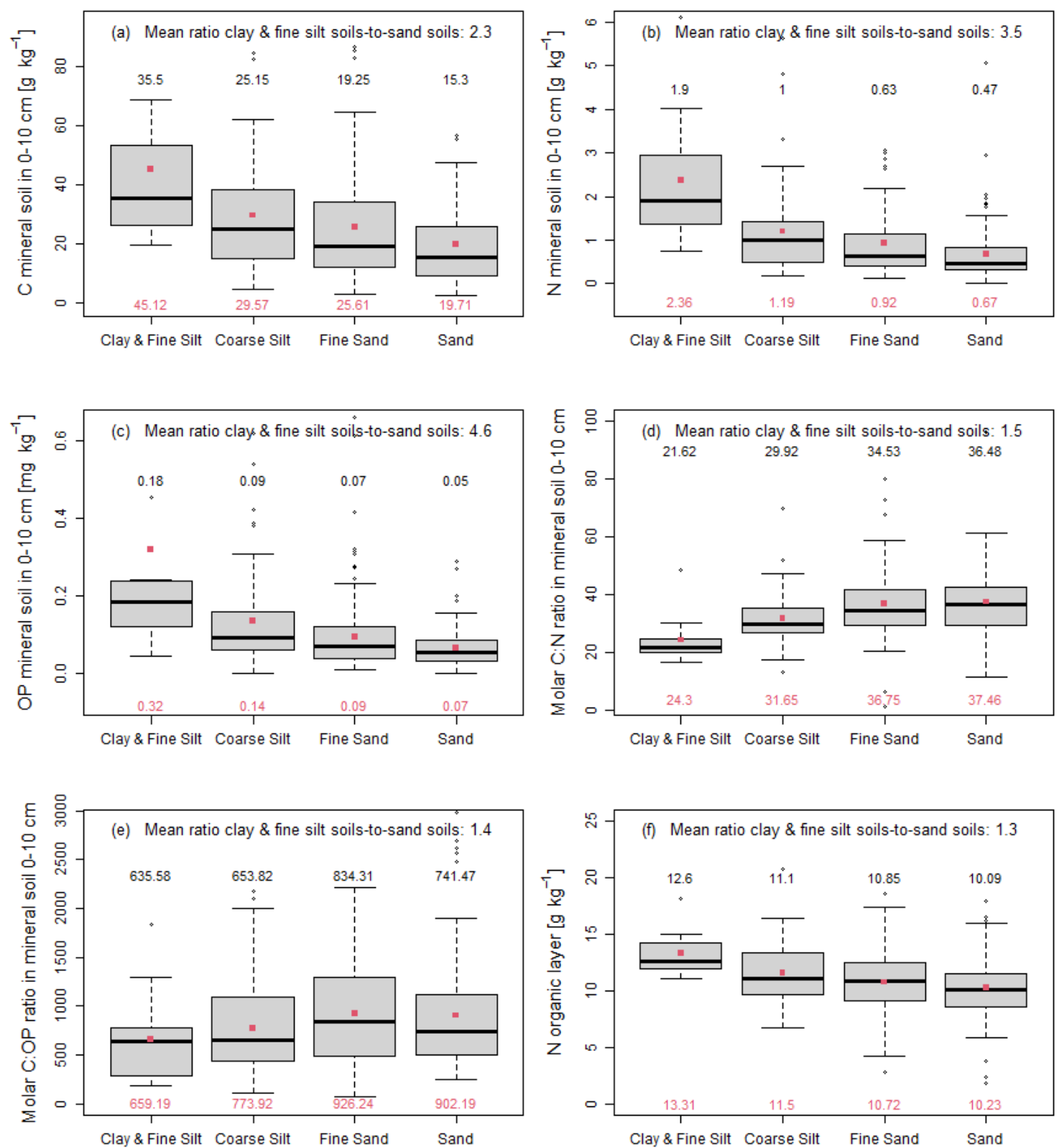

Figure 4: Carbon (a), nitrogen (b) and organic phosphorus (c) concentration, the molar carbon-to-nitrogen (C:N) ratio (d) and molar carbon-to-organic phosphorus (C:OP) ratio (e) in the mineral soil in a depth of 0-10 $\mathrm{cm}$ as well as the nitrogen $(\mathrm{N})$ stock of the organic layer (f) depending on the soil texture (clay and fine silt $n=11$, coarse silt $n=52$, fine sand $n=136$, and sand $\mathrm{n}=110$ ) in 309 Swedish forest soils with a stand age $>60$ years. The texture class called sand here encompasses sand and coarse sand. Black numbers give the median, red dots and red numbers depict the arithmetic mean. 
https://doi.org/10.5194/bg-2021-346

Preprint. Discussion started: 22 December 2021

(c) Author(s) 2021. CC BY 4.0 License.
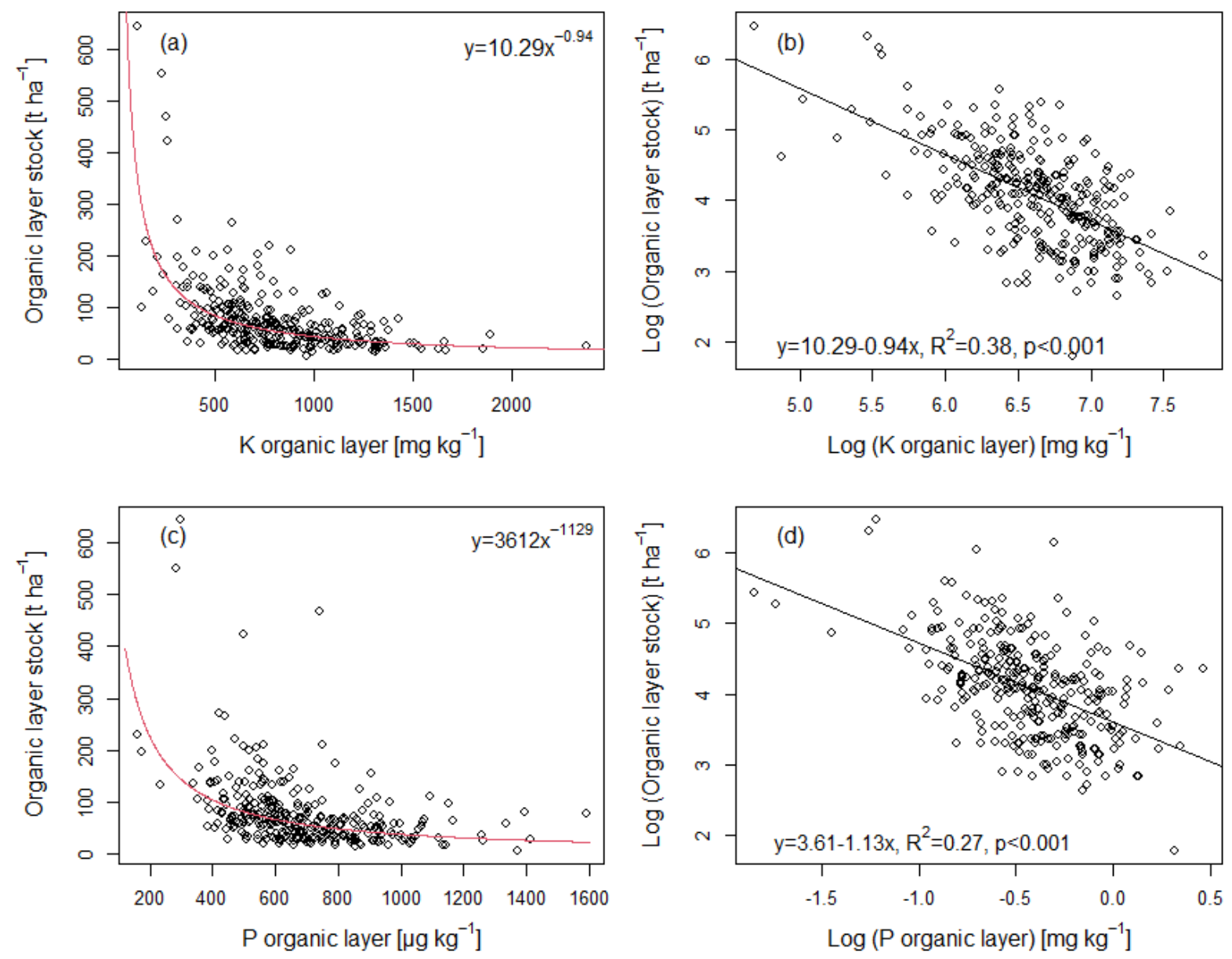

Figure 5: The organic layer stock as a function of the organic layer $\mathrm{K}$ concentration shown for the original data with a power function (a) and the log-transformed data with a linear model (b) as well as the organic layer stock as a function of the organic layer P concentration shown for the original data with a power function (c) and the log-transformed data with a linear model (d). 